https://doi.org/10.46344/JBINO.2020.v09i03.11

\title{
AYURVEDIC MANAGEMENT OF PSORIASIS (A CASE REPORT)
}

Dr. Aosemba Jamir' Dr. Jitendra Gauttam', Dr. Latika', Dr. Prasanth $D^{2}$, Dr. SantoshKumar Bhatted³.

1.P.G Scholar, ${ }^{2}$ Assistant Professor, ${ }^{3}$ Associate Professor,HOD, Depart of Panchakarma, AllA

\begin{tabular}{|c|}
\hline$A B S 1$ \\
\hline $\begin{array}{l}\text { Introduction- Psoriasis is a mentally agonising and a notoriously chronic autoimmune skin } \\
\text { disease. It is well known for its course of remission and relapses. Methods-The present } \\
\text { clinical study is a case report on the efficacy of Shamana(pacifying) medication, } \\
\text { Virechana(Therapeutic Purgation) and Raktamokshana(controlled bloodletting)in the } \\
\text { management of a patient diagnosed as erythrodermic psoriasis. Looking into the nature } \\
\text { of the disease, a controlled and stepwise management of the disease was planned, with } \\
\text { resolution of the disease as the primary objective. Results- PASI (Psoriatic assessment } \\
\text { severity Score) score improved significantly from } 30.5 \text { to 4.8. DLQI(Dermatological Life } \\
\text { Quality Index) improved from } 11 \text { to } 1 \text {. Discussion- The collected data from this study } \\
\text { suggests that Ayurvedic Dosha pratyanika Shodhana(measures of elimination of } \\
\text { physiological humours) treatment along with Shamanamedications having attributes } \\
\text { Kushtaghna(Alleviators of skin disorders), Medhya(brain tonic) and } \\
\text { Rasayana(Rejuvinative)can provide an efficient result for managing psoriasis. }\end{array}$ \\
\hline
\end{tabular}

Key words;- Psoriasis,Eka Kustha, Blood Letting, Sira vedha(venepuncture), Jalouka avaharana (leech therapy), Vamana,. 


\section{INTRODUCTION}

Psoriasis is a common autoimmune skin disease characterized by raised patches of abnormal skin. These skin patches are typically red, itchy and scaly. The exact etiology of Psoriasis is still unknown, but it is believed to have a genetic component. Multifactorial inheritance, most likely a familial history of psoriasis is found in $30 \%$ of patients. It is mediated by T-Cells. (DMT) Psoriasis is seen worldwide in all race and both sexes with a prevalence from 0.1 to $3 \% 1$. There are two epidemiological patterns of Psoriasis, First an onset in the teenage and early adult age. Such individuals frequently have a family history of psoriasis and there is increased prevalence of ( HLA)-CW6. In second pattern onset is in an individual's fifties or sixties, a family history is less common and HLA group CW6 is not so prominent. So triggering factors for Psoriasis are hereditary or having a family history, injury to skin, Hypercholesteremia, certain toxic drugs, emotional stress \& anxiety.

\section{KUSTHA W.r.t. PSORIASIS}

In Ayurveda, all skin diseases are grouped under a broad heading of Kushtha Roga.Eka kushtha is one of such disease explained under the heading of Kshudra Kushtha(minor skin ailments). Even though, in terms of Severity, Incidence and Prognosis, it is not a minor kind. The classical symptoms of Eka kushtha described in Ayurveda resembles with Psoriasis².

\section{Clinical features of Psoriasis [Rupa of Eka kushtha]}

- Reduced sweating (Asweda)

- Extended skin lesions(Mahavastu)

- Resemblance of the fish(Matsya shakalopama)

\section{Aim and objectives}

To evaluate the efficacy of Shamana medications and Virechana followed by Raktamokshana in the management of Plague Psoriasis.

\section{Case report}

A 33 year old Indian Female patient with height $166 \mathrm{~cm}$, weight $68 \mathrm{~kg}$, was referred to AllA Panchakarma OPD. She was a diagnosed case of Psoriasis since 13 years. She was presenting with symptoms such as erythema, scaling and itching of skin all over the body. 
Table 1: Astha vidha pariksha

\begin{tabular}{|c|c|c|}
\hline SL.no. & Factor & Observation \\
\hline 01 & Naadi & Kapha Vataj \\
\hline 02 & Mala & Ka-Ama \\
\hline 03 & Mutra & Malaavrata \\
\hline 04 & Jihwa & Spashta \\
\hline 05 & Shabda & AnushnaSheeta \\
\hline 06 & Sparsha & Normal \\
\hline 07 & Drik & KaphaPittaja \\
\hline 08 & Akriti \\
\hline
\end{tabular}

Table2: Dasha Vidha Pariksha

\begin{tabular}{|c|c|c|}
\hline Sl.no. & Factor & Observation \\
\hline 01 & Prakriti & KaphaVataj \\
\hline 02 & Vikriti & Tridoshaja (Kapha Vata Pradhana) \\
\hline 03 & Saara & Meda \\
\hline 04 & Samhanana & Madhyama \\
\hline 05 & Satmya & Madhyama \\
\hline 06 & Satwa & Madhyama \\
\hline 07 & Aharashakti & Madhyama \\
\hline 08 & Vyayamashakti & Madhyama \\
\hline 09 & Vaya & \\
\hline 10 & Bala & \\
\hline
\end{tabular}

\section{MATERIALS AND METHODS}

Diagnosis

Psoriasis- The patient was diagnosed as a case of Psoriasis by identifying its characteristic lesion i.e, itchy, deep pink to reddish, well demarcated, indurated plagues with silvery-micaceous scaling present particularly over the extensor surfaces.

Table3: TREATMENT PLAN in Chronological order

\begin{tabular}{|c|c|c|c|}
\hline Sl.No. & Treatment Plan & Days & Assessment Time \\
\hline 01 & Shamana/Deepana Pachana & BT \\
\hline 02 & Sneha Pana & $1^{\text {st }}-15^{\text {th }}$ day & \\
\hline 03 & Abhyanga $/$ Swedana & $16^{\text {th }}-22^{\text {nd }}$ day & \\
\hline 04 & Vamana & $23^{\text {rd }}-24^{\text {th }}$ day & AT1 \\
\hline 05 & Samsarjana Krama & $24^{\text {th }}$ day & AT2 \\
\hline 06 & Shamana & $24^{\text {th }}-28^{\text {th }}$ day & AT3 \\
\hline 07 & Sira Vyadha & $29^{\text {th }}-59^{\text {th }}$ day & \\
\hline 08 & Jalouka Avacharana & $59^{\text {th }}$ and $74^{\text {th }}$ day & \\
\hline 09 & $\begin{array}{c}\text { Follow up at an interval of } 15 \\
\text { days for a month from the end of } \\
\text { Jalouka Avacharana (Shamana } \\
\text { Medication was being continued } \\
\text { from the end of Samsarjana } \\
\text { Karma till follow up) }\end{array}$ & $117^{\text {th }}$ day and $132^{\text {th }}$ day & \\
\hline $\mathbf{1 0}$ & Total duration of treatment & & \\
\hline
\end{tabular}

Table 4: Shamana /Deepana Pachana medicines

\begin{tabular}{|c|c|c|c|}
\hline Sl.no. & $\begin{array}{l}\text { Treatment } \\
\text { given }\end{array}$ & Mrdicine used & Dose \\
\hline & \multirow[t]{4}{*}{ Shamana } & Kaishore Guggulu $^{7}$ & $\begin{array}{l}2 \text { tab (three times a day before } \\
\text { food) }\end{array}$ \\
\hline & & $\begin{array}{c}\text { Mahamanjisthadi Kashaya }^{8} \\
\text { (ah } 15 / 17 \text { 202) }\end{array}$ & $\begin{array}{c}15 \mathrm{ml} \text { (three times a day before } \\
\text { food) }\end{array}$ \\
\hline & & Saraswata arista ${ }^{9}$ & $\begin{array}{l}15 \mathrm{ml} \text { (three times a day after } \\
\text { food) }\end{array}$ \\
\hline & & Arogyavardhini vati ${ }^{10}$ & $\begin{array}{c}2 \text { tab (two times a day after } \\
\text { food) }\end{array}$ \\
\hline
\end{tabular}




\begin{tabular}{|c|c|c|}
\hline & Amlaki Choorna ${ }^{I I}$ & $\begin{array}{c}3 \mathrm{gm} \text { (two times a day after } \\
\text { food) }\end{array}$ \\
\hline & Pancha Nimbadi Choorna ${ }^{12}$ & $\begin{array}{c}3 \mathrm{gm} \text { (two times a day before } \\
\text { food) }\end{array}$ \\
\hline $\begin{array}{l}\text { Deepan } \\
\text { Pachana }\end{array}$ & ${\text { Chitrakadi } \text { Vati }^{13}}^{13}$ & $\begin{array}{c}\text { 1tab (three times a day before } \\
\text { food) }\end{array}$ \\
\hline Snehapana & Tikta ghrita $^{14}$ & $750 \mathrm{ml}$ \\
\hline $\begin{array}{c}\text { Sarvanga } \\
\text { Abhayanga }\end{array}$ & Nalpamaradi keram $^{15}$ & $200 \mathrm{ml}$ \\
\hline $\begin{array}{c}\text { Bashpa } \\
\text { Swedana }\end{array}$ & Dashmooladi kwatha ${ }^{16}$ & $100 \mathrm{gm}$ \\
\hline \multirow[t]{4}{*}{ Vamana } & Madanphala & $10 \mathrm{gm}$ \\
\hline & Vacha choorna & $2 \mathrm{gm}$ \\
\hline & Madhu & $10 \mathrm{gm}$ \\
\hline & Saindhava lavana & $1 \mathrm{gm}$ \\
\hline \multirow[t]{2}{*}{ Virechana } & Trivrita Avaleha/Trivrit Kulsambu ${ }^{17}$ & $90 \mathrm{gm}$ \\
\hline & Triphala kwatha ${ }^{18}$ & $100 \mathrm{ml}$ \\
\hline
\end{tabular}

\section{Materials for Rakta mokshana}

1. Sira Vyadha ${ }^{19}$

(a) Scalp Vein Set 20 Gauge- 4 per sitting

(b) Cotton Roll 75gm

(c) Surgical Spirit $50 \mathrm{ml}$

2. Jalouka Avacharana ${ }^{20}$
(a) 8 Jalouka (Hirudo medicinalis) 5-6 cm in size
(b) Triphala Choorna 100gm for Gharshan (ss ch 37 sh $56 \& 57$ page 316 \&317)
(c) Shata Dhauta Ghrita (made in AIIA hospital)
(d) Cotton Roll 100gm
(e) Turmeric Powder 100gm
(f) Saindhava Lavana(rocksalt) $100 \mathrm{gm}$
(g) Hypodermic needle $22 \mathrm{G}$
(h) Bandage roll (2 inch Wide) 4 No.

\section{Discussion-}

Eka Kustha being a Kapha Vata predominanat disease, a planned protocol for elimination of kapha, pitta and impure blood and pacification with bitter and astringent drugs was undertaken as mentioned by Acharya Charaka.

The basic line of management with Shamana medications being selected for the treatment of concerned disease is focused mainly on the medications having attributes Kushtaghna, Medhya and Rasayanaproperties.

\section{Deepana Pachana with Shamana} medications was planned with drugs consisting of mainly Tikta(bitter) and Kashaya(astringent) Rasa taste.
Kaishore guggulu alleviates all skin disorders when used with lukewarm water or Mahamanjisthadi kwatha. It is also indicated in Manda Agni which was essential for Agni deepana in Kustha.Kaishore guggulu is a good blood purifier with anti inflammatory properties. ${ }^{21}$

Amlaki choorna has both Deepana Pachana property and is Medhya, and Kusthaghna. Amlaki choorna is widely used as a Rasayana. It has also potent anti oxidant property 22 .

Arogyavardhini Vati has Deepana Pachana properties, it is indicated in Kustha and Jwara.

Saraswata Arista having Medhya, Rasayana and Sarva Dosha Hara 
properties was prescribed to mitigate the mental stress of the patient.

Panchanimbadi Choorna mitigates diseases originated due to vitiation of Pitta and Kapha Dosha. It is indicated in all types of Kustha and all Raktaj Rogas.

Vamana was done considering the predominance of the symptoms of Kapha dosha such as whiteness, coldness, itching, stable patches and feeling of heaviness.

Follow up was done weekly for one month keeping the patient on the foresaid Shamana medication. Due to lack of desired outcome of the treatment, the next step of management was undertaken.

Considering the stable, deep seated hard patchy lesion, Rakta Mokshana was planned via Sira vyadha.Sira vyadha being the choice of Bloodletting since it evacuates the impurities from whole of the body.

After observing the mitigation of Sign and symptoms of Psoriasis via Sira vyadha,Jalouka Avacharana was planned as it is also indicated in Alpa Kustha ${ }^{23}$. Moreover Jalauka Avacharana is indicated for relieving the Pittaja predominant symptoms, which seemed essential to manage erythema as dominant sign at that time. Based on this principle, Jalouka avacharana was deduced as the suitable means for bloodletting. It is also considered the most gentle amongst the bloodletting procedures which was necessary for regular blood letting 24 .

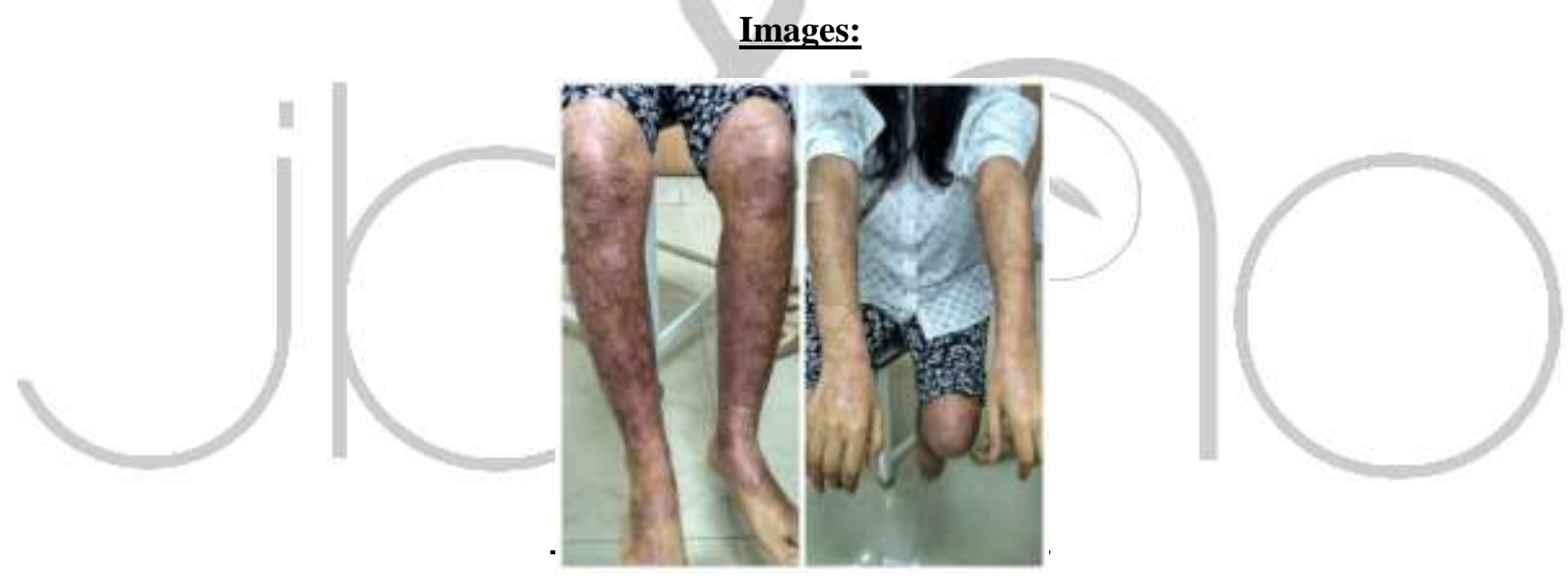

$\underline{\text { Image 1. Before treatment }}$

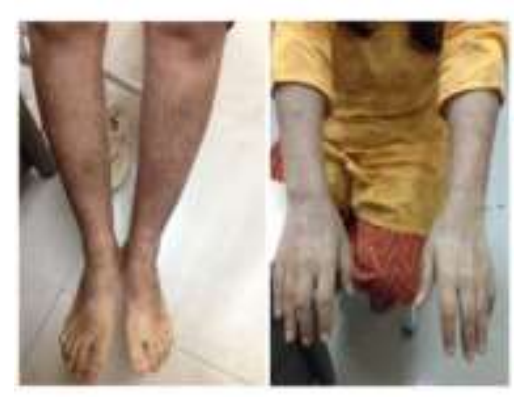

Image 2. After treatment 


\section{PASI Score and DLQI Score}

PASIScore DLQI Score

40

30.5

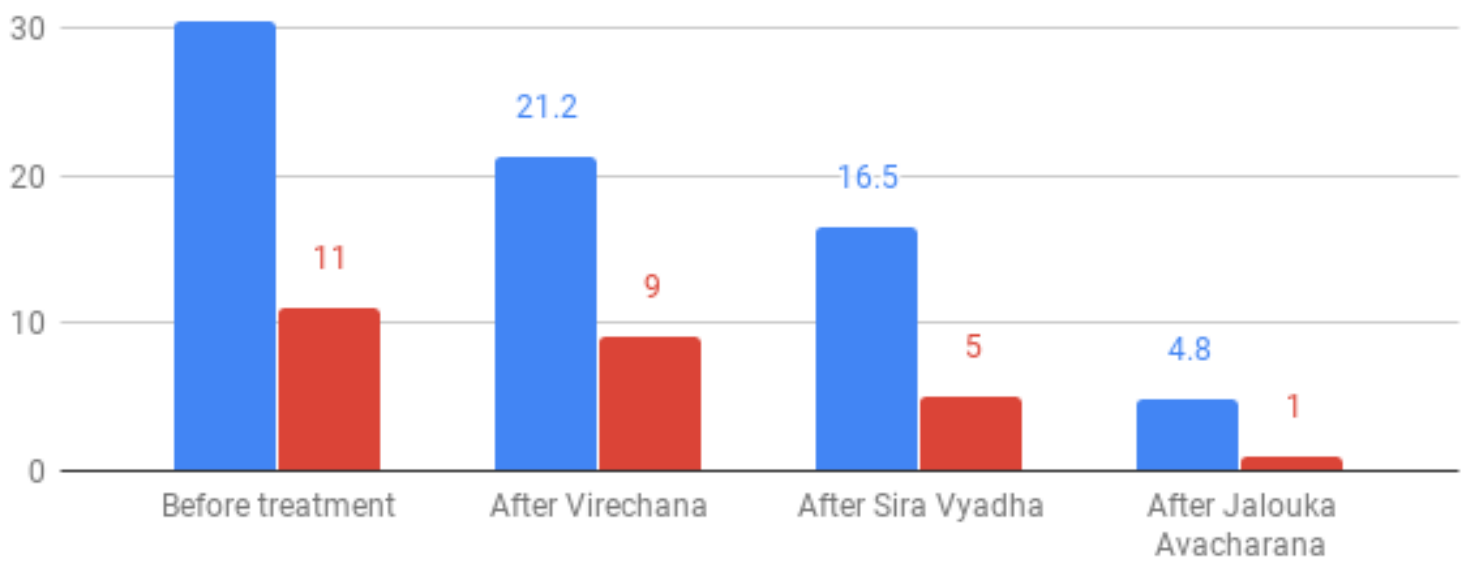

Table5: PASI Score ${ }^{25}$ OVERALL ASSESSMENT

\begin{tabular}{|c|c|c|c|c|}
\hline \multirow{2}{*}{$\begin{array}{c}\text { PASI SCORE } \\
111\end{array}$} & $\begin{array}{c}\text { Before } \\
\text { treatment }\end{array}$ & $\begin{array}{c}\text { After } \\
\text { Virechana }\end{array}$ & $\begin{array}{c}\text { After Sira } \\
\text { Vyadha }\end{array}$ & $\begin{array}{c}\text { After Jalouka } \\
\text { Avacharana }\end{array}$ \\
\cline { 2 - 5 } & 30.5 & 21.2 & 16.5 & 4.8 \\
\hline
\end{tabular}

Table6: AUZPITZ SIGN ${ }^{26}$

\begin{tabular}{|l|c|c|c|c|}
\hline Auzpitz sign & $\begin{array}{c}\text { Before } \\
\text { treatment }\end{array}$ & $\begin{array}{c}\text { After } \\
\text { Virechana }\end{array}$ & $\begin{array}{c}\text { After Sira } \\
\text { Vyadha }\end{array}$ & $\begin{array}{c}\text { After Jalouka } \\
\text { Avacharana }\end{array}$ \\
\cline { 2 - 5 } & Present & Present & Present & Absent \\
\hline
\end{tabular}

Tale7: DERMATOLOGICAL LIFE QUALITY INDEX SCORE ${ }^{27}$

\begin{tabular}{|c|c|c|c|c|}
\hline DERMATOLOGICAL & $\begin{array}{c}\text { Before } \\
\text { LIFE QUALITY } \\
\text { InDEX SCORE }\end{array}$ & $\begin{array}{c}\text { After } \\
\text { Virechana }\end{array}$ & $\begin{array}{c}\text { After Sira } \\
\text { Vyadha }\end{array}$ & $\begin{array}{c}\text { After Jalouka } \\
\text { Avacharana }\end{array}$ \\
\cline { 2 - 5 } & 11 & 9 & 5 & 1 \\
\hline
\end{tabular}

\section{RESULT}

PASI score improved significantly from 30.5 to 4.8. DLQI improved from 11 to 1. Auzpitz sign resolved to negative. Symptoms such as erythema, induration, itching and scaling reduced significantly.

\section{CONCLUSION}

Lastly it can be concluded with this clinical study that Ayurvedic treatment is effective in the management of Psoriasis when managed on the line of treatment of Eka kustha, and it will give encouraging results, since no complication was 2020 May Edition | www.jbino.com | Innovative Association observed in this clinical study. Such kind of research work may be designed in future for more conformation to provide the better Ayurvedic treatment on the management of complicated cases of Psoriasis.

\section{REFERENCES}

API Text book of medicine Volume 1, 10 Th edition, Jaypee Brothers Medical 
Publishers (P) Ltd,Part11 chapter 4, page 678.

Psoriasis (Ekakustha) through Ayurveda-A case study,IAMJ: Volume 3; Issue 8; August-2015.

Sharangadhar Samhita of Sharangadhar Translated by Prof.K.R. Srikanth Murthy, Published by Chaukhamba Orientalia, Reprint Edition 2016,Ch.4 Shlokal3,Page. 17

Charaka Samhita of Agnvesha Edited and Translated by Prof. Priyavrat Sharma, Published by Chaukhamba Orientalia, Edition-2014 Vol.I.Shaarira Sthana Ch.13, Page 85-94.

Sushruta Samhita edited by G.D.Singhal And Colleague Second edition 2007 published by Chaukhamba Sanskrit Pratishthan part- Su.Chi 33/46 Page3 16.

Charaka Samhita of Agnvesha Edited and Translated by Prof. Priyavrat Sharma, Published by Chaukhamba Orientalia, Edition-2014 Vol.2 Siddhi Sthana Ch.1/11 page 588.

Sharangadhar Samhita of Sharangadhar Translated by Prof.K.R. Srikanth Murthy, Published by Chaukhamba Orientalia, Reprint Edition 2016, Second Section, Ch.7/70-81, Page. 107.

Sharangadhar Samhita of Sharangadhar Translated by Prof.K.R. Srikanth Murthy, Published by Chaukhamba Orientalia, Reprint Edition 2016,Second section, Ch.2/137-143,Page72-73.

Bhaishajya Ratnavali Of Govinda Dasji Bhisagratna Commented upon by
Vaidya Shri Ambika Datta Shastri, English Translation by Dr.Kanjiv Lochan, Edition:Reprint,2014, Vol2 ,Chapter73, Page 506-50.

Ras Ratna Sammuchaya of Vagbhata Acharyam Translated by Dr. Indra Dev Tripathi, publishe by Chowkhamna Sanskrit Sansthana, Reprint 2013, Chapter 20/87-93 Page-252.

Charaka Samhita of Agnvesha Edited and Translated by Prof. Priyavrat Sharma, Published by Chaukhamba Orientalia, Edition-2014 Vol.2 Chikitsa Sthana Ch.1/36 page.469-470.

Bhaishajya Ratnavali Of Govinda Dasji Bhisagratna Commented upon by Vaidya Shri Ambika Datta Shastri, English Translation by Dr.Kanjiv Lochan, Edition:Reprint,2014, Vol2 ,Chapter54/7679 Page298.

Charaka Samhita of Agnvesha Edited and Translated by Prof. Priyavrat Sharma, Published by Chaukhamba Orientalia, Edition-2014 Vol.2.Chikitsa Sthana Ch.15/96-97.

Sahasrayogam English Translation by Dr. K Niteshwar And Dr, R Vidyanath,Published by Chowkhamba Sanskrit Series Office, Varanasi, Fourth Edition 2014, Chapter 2 Page 58.

Sahasrayogam English Translation by Dr. K Niteshwar And Dr, R Vidyanath, Published by Chowkhamba Sanskrit Series Office, Varanasi, Fourth Edition 2014, Chapter 11 page 406.

Sahasrayogam English Translation by Dr. K Niteshwar And Dr, R Vidyanath, Published 2020 May Edition | www.jbino.com | Innovative Association 
by Chowkhamba Sanskrit Series Office, Varanasi, Fourth Edition 2014, Chapter 10/61 page 384.

Sahasrayogam English Translation by Dr. K Niteshwar And Dr, R Vidyanath, Published by Chowkhamba Sanskrit Series Office, Varanasi, Fourth Edition 2014, Chapter 7/38 page 291.

Sushruta Samhita edited by G.D.Singhal And Colleague Second edition 2007 published by Chaukhamba Sanskrit Pratishthan part-1 SU.SU. 14/25 Page 120.

Sushruta Samhita edited by G.D.Singhal And Colleague Second edition 2007 published by Chaukhamba Sanskrit

Pratishthan Part-1 SU.SU. 13 Page 107-114. Sushruta Samhita edited by G.D.Singhal And Colleague Second edition 2007 published by Chaukhamba Sanskrit Pratishthan Part-1 Su.Su. 13/56-57 Page 316-317
An Ayurvedic Polyherbal Formulation Kaishore Guggulu:A Review, IJPBA, JanFeb, 2011, Vol2, Issue, 1.

Amlaki Indian Journal of Experimental Biology, Vol.37, July 1999,pp 676-680.

Charaka Samhita of Agnvesha Edited and Translated by Prof. Priyavrat Sharma, Published by Chaukhamba Orientalia, Edition-2014 Vol.2.Chikitsa Sthana Ch.7/51 page.129-130.

Sushruta Samhita edited by G.D.Singhal And Colleague Second edition 2007 published by Chaukhamba Sanskrit Pratishthan part-1 Su.Su. 13/3 Page 107.

PASI "Psoriasis Update -Skin \& Aging". Retrieved 2007-07-28

Auzpitz sign in psoriasis scale,JAAD, April 1977, Volume 36, Issue4, Page 621.

DLQI Basra MKA, Fenech R, Gatt RM, Salek MS, Finlay AY. The Dermatology Life Quality Index 1994-2007: A comprehensive review of validation data and clinical results. British Journal of Dermatology 2008; 159: 997-1035 